\title{
PENERAPAN KONSEP MUBADALAH DALAM POLA PENGASUHAN ANAK
}

\author{
Wilis Werdiningsih ${ }^{1}$
}

\begin{abstract}
Abstrak
Pola pengasuhan anak yang tidak mencerminkan kesetaraan dan keadilan gender dapat membentuk perilaku anak yang tidak responsif gender. Pendidikan pada keluarga sering kali menjadi penyebab terjadinya ketidakadilan gender dalam kehidupan masyarakat. Tantangan besar dalam mewujudkan kesetaraan dan keadilan gender adalah merubah cara pandang dikotomis pada jenis kelamin laki-laki dan perempuan. Dalam cara pandang ini, laki-laki dan perempuan dianggap berbeda, sehingga keduanya nampak bertentangan satu sama lain. Merubah cara pandang dikotomis menjadi hal yang penting dilakukan demi terwujudnya kesetaraan dan keadilan gender yang dapat dimulai dari kehidupan keluarga. Konsep mubadalah merupakan satu konsep yang membahas tentang kesetaraan gender dengan menekankan pada prinsip kesalingan untuk sama-sama mengambil manfaat dari dua orang yang berrelasi. Perempuan maupun laki-laki memiliki hak dan kesempatan yang sama untuk berkiprah di ranah publik maupun domestik, dan mengambil manfaat dari segala aspek kehidupan. Maka penelitian ini bertujuan untuk mengkaji penerapan konsep mubadalah dalam pola pengasuhan anak. Metode library research digunakan melalui penggalian informasi dari berbagai literatur yang terkait dengan konsep mubadalah dan pola pengasuhan anak. Hasil menunjukkan bahwa konsep mubadalah merupakan salah satu konsep dalam kesetaraan gender yang dapat diterapkan dalam pola pengasuhan anak di dalam kehidupan keluarga. Melalui penerapan konsep ini, maka pola pengasuhan anak menjadi responsif gender dengan meninggalkan segala hal yang bias gender.
\end{abstract}

Kata kunci: konsep mubadalah, pola pengasuhan anak.

${ }^{1}$ Dosen IAIN Ponorogo email: werdiningsih@iainponorogo.ac.id 


\section{PENDAHULUAN}

Allah Swt. menciptakan manusia di bumi ini dengan dua jenis kelamin, yakni perempuan dan laki-laki. Dari beberapa ayat dalam Al Quran ditegaskan bahwa baik laki-laki maupun perempuan dari asal kejadiannya maupun tujuan diciptakannya adalah sama. Manusia diciptakan oleh Allah Swt. sebagaimana dalam QS Al Baqarah:20, adalah sebagai khalifah di bumi. Tugas kekhalifahan manusia ini dibebankan tidak hanya kepada satu jenis kelamin tertentu saja, melainkan kepada manusia secara umum. Sehingga keduanya, baik laki-laki maupun perempuan memiliki tanggung jawab yang sama untuk menjaga bumi dari kerusakan sebagaimana perintah dari Allah Swt. dalam ayat tersebut.

Laki-laki dan perempuan merupakan jenis kelamin yang diciptakan oleh Allah Swt. Adanya jenis kelamin laki-laki dan perempuan, memberikan konsekuensi perbedaan alat kelamin yang dimiliki. Laki-laki memiliki penis, kantong sperma dan sperma. Sementara perempuan memiliki vagina, indung telur, sel telur, rahim, hormon prolaktin (kelenjar mamae). Alat kelamin yang juga merupakan alat reproduksi yang dimiliki tersebut, memberikan konsekuensi perbedaan pengalaman reproduksi (pengalaman biologis) antara laki-laki dan perempuan. Laki-laki mengalami mimpi basah, sementara perempuan mengalami menstruasi, kehamilan, melahirkan, nifas dan menyusui. Jika mimpi basah hanya berlangsung 5 menit, maka pengalaman biologis perempuan berlangsung lebih lama, sampai dengan kurun waktu 2 tahun (menyusui). Oleh sebab itu, semestinya perbedaan yang berkaitan dengan jenis kelamin, berhenti pada titik di mana perempuan telah melaksanakan perannya untuk hamil, melahirkan dan menyusui. Selebihnya peran laki-laki dan perempuan dalam ranah publik, maupun domestik adalah sama. Jika perempuan memiliki tanggung jawab dalam hal pengasuhan anak dan segala yang berkaitan dengan keperluan rumah tangga, maka laki-lakipun juga memiliki tanggung jawab yang sama. Begitupun untuk tanggung jawab dalam rumah tangga yang lainnya.

Perbedaan pengalaman biologis sudah semestinya menjadi hal yang diperhatikan berkaitan dengan kekhususan seorang perempuan. Penekanan pemberian perhatian sesuai dengan kebutuhan perempuan yang sedang mengalami pengalaman biologis menjadi hal yang penting sebagai upaya mewujudkan keadilan yang hakiki. Keadilan hakiki dimaknai sebagai bentuk keadilan yang diberikan kepada laki-laki maupun perempuan sesuai dengan porsi kebutuhan masingmasing, yang tidak mesti sama. Keadilan hakiki dapat terwujud dengan memperhatikan dua hal, yakni apakah pengalaman biologis yang dirasakan perempuan tidak semakin sakit?, dan dalam asumi kebaikan apakah perempuan dipastikan tidak mengalami lima pengalaman sosial (stigmatisasi, marjinalisasi, subordinasi, violence, beban ganda)?.2

\footnotetext{
2 Nur Rofi'ah, wawancara, Ponorogo, 27 November 2019
} 
Namun dalam kenyataannya, masih banyak sekali terjadi ketidaksetaraan gender di dalam kehidupan masyarakat. Segala kegiatan seringkali dianggap memiliki jenis kelamin sebagaimana jenis kelamin itu sendiri. Asumsi inilah yang menjadi dasar kepantasan laki-laki dan perempuan untuk berbuat dan tidak berbuat di dalam kehidupan masyarakat. Dalam catatan sejarah, sistem patriarki memiliki andil yang besar terhadap terjadinya ketidakadilan gender. Sistem patriarki adalah sistem nilai yang meletakkan jenis kelamin laki-laki secara vertikal di atas perempuan. Laki-laki merupakan subjek kehidupan, sementara perempuan adalah objek. Terdapat dua sistem patriarki, yakni patriarki garis keras dan patriarki lebih lunak. Dalam patriarki garis keras, laki-laki dipandang sebagai subjek tunggal kehidupan sementara perempuan objek. Sedangkan patriarki garis lebih lunak adalah sistem sosial yang menempatkan laki-laki sebagai subjek utama/primer dalam kehidupan, sementara perempuan merupakan subjek sekunder. Sehingga dalam sistem patriarki garis lebih lunak, perempuan mendapatkan kesempatan untuk bicara dan berpendapat, akan tetapi keputusan akhir adalah hak dari laki-laki. Meskipun sudah memberikan ruang yang lebih baik dalam patriarki garis lebih lunak dibandingkan dengan patriarki garis keras, namun tetap tampak pemosisian perempuan berada di bawah laki-laki. Maka yang harus diwujudkan dalam kehidupan manusia agar terjadi keseimbangan dalam kehidupan manusia adalah kesetaraan antara laki-laki dan perempuan/kesetaraan gender. Dalam kesetaraan gender, laki-laki dan perempuan merupakan dipandang sama-sama sebagai subjek kehidupan. Sebagai subjek, maka laki-laki dan perempuan mendapatkan kesempatan yang sama untuk berbicara, berperan dan mengambil keputusan dalam kehidupan dalam kerangka kemaslahatan bersama. Segala sesuatu tidak dipandang berdasarkan jenis kelamin.

Kesetaraan dan keadilan gender perlu ditanamkan pada anak sedini mungkin agar anak memiliki pemahaman yang diwujudkan melalui perilaku tentang kesetaraan gender. Masa usia dini merupakan masa yang tepat untuk menerapkan pengasuhan yang responsif gender sebagai salah satu upaya untuk memutus mata rantai budaya bias gender sejak dini. ${ }^{3}$ Hal ini penting, sebab masih banyak sekali hal-hal yang tanpa disadari di dalam kehidupan masyarakat masih menunjukkan adanya indikator ketidakadilan gender baik di dalam kehidupan nyata maupun di media massa. Ketidakadilan gender ini dapat dilihat dari empat indikator yakni akses, partisipasi, kontrol dan manfaat.

Dalam bukunya, Faqihuddin Abdul Qadir menjelaskan bahwa salah satu tantangan serius ikhtiar mewujudkan keadilan gender adalah merubah cara pandang dikotomis pada laki-laki dan perempuan. Laki-laki dan perempuan

${ }^{3}$ Evi Muafiah dkk, "Pengasuhan Anak Usia Dini Berspektif Gender Dalam Hubungannya Terhadap Pemilihan Permainan Dan Aktivitas Keagamaan Untuk Anak," Jurnal Palastren 12 (June 2019): 4. 
dianggap berbeda sehingga keduanya dilihat bertentangan satu sama lain. ${ }^{4}$ Salah satu pihak memiliki keharusan untuk menaklukkan pihak lain, sebab jika tidak demikian maka ia akan ditaklukkan. Konsep mubadalah merupakan konsep dalam kesetaraan gender yang menekankan pada relasi kemitraan atau kesalingan antara dua belah pihak yang bermitra dengan tujuan keduanya dapat mengambil manfaat dari kegiatan relasi tersebut. Kehidupan di keluarga merupakan tempat di mana anak belajar secara awal tentang berbagai hal. Pola pengasuhan anak menjadi titik awal mengajarkan kepada anak tentang hal-hal sederhana yang mewujudkan kesetaraan gender. Kesetaraan gender menjadi penting untuk ditekankan pada anak sedini mungkin, agar dalam kehidupan bermasyarakat anak menjadi seseorang yang mendorong terjadinya kesetaraan gender. Berangkat dari permasalahan di atas, maka judul dalam penelitian ini adalah penerapan konsep mubadalah dalam pola pengasuhan anak.

\section{PEMBAHASAN}

\section{Metode Penelitian}

Penelitian ini menggunakan pendekatan kualitatif dengan jenis library research. Sumber data dalam penelitian ini terdiri dari data dokumenter yang berupa dokumen-dokumen terkait dengan konsep mubadalah dalam kesetaraan gender dan pola pengasuhan anak. Analisis yang digunakan ialah analisis konten (content analysis). Penelitian ini bertujuan untuk mendeskripsikan dan membuat kesimpulan yang valid dan dapat diteliti ulang. Bagian yang dianalisis adalah penerapan konsep mubadalah dalam pola pengasuhan anak. Prosedur analisis konten yang digunakan terdiri atas empat langkah, yaitu pengadaan data, reduksi data, inferensi dan analisis data. Tahap pengadaan data terdiri dari 3 bagian yaitu penentuan unit analisis, penentuan sampel dan perekaman atau pencatatan. Reduksi data dilakukan dengan menghilangkan hal-hal yang tidak sesuai dengan kajian kesetaraan gender yang dianalisis. Inferensi dilakukan dengan menggunakan kriteria penentuan konsep mubadalah dalam kajian kesetaraan gender. Tahap analisis data merupakan tahap pendeskripsian data analisis yang diperoleh. Analisis data menggunakan teknik analisis kualitatif.

\section{Pendidikan Anak Usia Dini}

Anak usia dini memiliki kekhususan yang berbeda dengan orang dewasa. Mereka bukanlah miniatur dari orang dewasa sehingga harus dipahami dengan segala yang menjadi kebutuhannya. Usia dini seringkali disebut sebagai masa golden age. Sebab pada masa ini perkembangan otak anak terjadi dengan sangat pesat yang mencapai $50 \%-80 \%$ dari keseluruhan perkembangan usia selama hidupnya. ${ }^{5}$ Anak usia dini

\footnotetext{
4 Faqihuddin Abdul Kodir, Qira'ah Mubadalah (Yogyakarta: Ircisod, 2019), 28.

${ }^{5}$ Mariyana Dkk, Pengelolaan Lingkungan Belajar (Jakarta: Kencana Perdana Media Group, 2010),
} 11. 
berdasarkan UU Sisdiknas nomor 20 tahun 2003, adalah anak yang memiliki usia 0-6 tahun. Oleh sebab itu pada usia tersebut anak memerlukan rangsangan/stimulus agar otak berkembang dengan pesat, termasuk memastikan lingkungan yang kondusif bagi pertumbuhan dan perkembangan anak. Selain itu usia PAUD merupakan masa peka bagi anak, di mana anak mulai sensitif untuk menerima berbagai upaya perkembangan seluruh potensi anak. Masa peka adalah masa terjadinya pematangan fungsi-fungsi psikis dan fisik yang siap merespon stimulasi yang diberikan oleh lingkungan. Masa ini merupakan masa peletakkan dasar pertama dalam mengembangkan kemampuan fisik, kognitif, bahasa, sosial emosional, konsep diri, disiplin, kemandirian, seni, moral dan nilai-nilai agama. ${ }^{6}$

Salah satu hal yang penting untuk diperhatikan berkaitan dengan pertumbuhan dan perkembangan anak adalah kegiatan bermain. Sebab melalui kegiatan bermain anak dapat mengembangkan berbagai kemampuannya dengan baik. Sebagaimana yang disampaikan oleh Shoba Dewey Cughani bahwa berkembangnya berbagai kemampuan anak adalah sebuah proses. Hal ini dapat dirangsang dengan pemberian rangsangan/stimulasi yang sesuai dengan perkembangan anak usia dini yaitu melalui kegiatan bermain. Bermain adalah pekerjaan anak. ${ }^{7}$ Melalui permainan orang dewasa memiliki banyak kesempatan untuk mengajarkan berbagai hal kepada anak, baik tentang budi pekerti, matematika, membaca, ataupun menulis. ${ }^{8}$ Sehingga dapat disimpulkan bahwa yang terpenting dalam kegiatan belajar adalah memadukan kegiatan tersebut dengan kekhususan dunia anak yakni melalui kegiatan bermain. Melalui kegiatan bermain segala hal yang ingin diajarkan kepada anak menjadi lebih mudah karena anak tidak merasa mereka belajar meskipun sebenarnya mereka sedang belajar. Sebagaimana dikatakan Rousseau, filsuf abad 18 (dalam Santrock, 2004), setiap anak dilahirkan dengan kemampuan belajar. Namun seringkali anak-anak kehilangan minat belajar jika materi yang diberikan terlalu mudah atau terlalu sulit. Maka materi perlu dikemas sesuai dengan tahap perkembangan anak, melalui kegiatan yang bermakna. ${ }^{9}$ Bagi anak usia dini, proses lebih bermakna dari pada hasil. Fokus pada hasil akhir saja, sebenarnya mempersempit peluang untuk melatih berbagai aspek perkembangan pada anak.

Dalam sebuah acara seminar parenting, dijelaskan oleh Kang Maman, pendiri sekolah alam yang berada di Solo, bahwa perkembangan anak secara berturut-turut dimulai dari perkembangan fisik, bahasa, kognitif, keterampilan, seni dan sosial. ${ }^{10}$

${ }^{6}$ Naomi Habi Atal dan Mariana Ikun RD Pareira, “Peningkatan Kemandirian Anak Usia 4-5 Tahun Melalui Bercerita," Jurnal PG PAUD Trunojoyo VI (2019): 36.

7 Shoba Dewey Chugani, Anak Yang Cerdas Anak Yang Bermain (Jakarta: PT Gramedia Pustaka Utama, 2009), 3.

8 Chugani, 9.

${ }^{9}$ Chugani, 12.

${ }^{10}$ Kang Maman, wawancara, Ponorogo, 19 Oktober 2019. 
Oleh sebab itu yang terpenting pada awal pendidikan anak adalah memastikan kondisi fisik anak kuat. Kondisi fisik mencakup kekuatan kaki yang dapat digunakan untuk berjalan, berlari, melompat maupun kegiatan motorik kasar maupun motorik halus lainnya dan kekuatan tangan untuk melakukan berbagai kegiatan yang mengasah keterampilan motorik halus seperti meremas, menyikat gigi, melukis, menggambar, mencuci tangan dan membuka menutup kancing baju. Selanjutnya keterampilan bahasa menjadi hal yang perlu untuk diperhatikan agar anak dapat berkomunikasi dengan baik dengan orang lain. Sedangkan keterampilan kognitif berada pada urutan ketiga yang diikuti dengan perkembangan seni dan sosialnya.

Seorang anak, punya dorongan alamiah untuk meniru apa yang dikerjakan orang dewasa untuk belajar menjadi mandiri dan bertanggung jawab. Jika ia diberikan kesempatan, maka kemandirian, kepercayaan diri serta tanggung jawabnya akan terus berkembang. Sebagaimana disampaikan oleh Chugani, "sesungguhnya anak yang mandiri, percaya diri dan bertanggung jawab akan lebih siap menghadapi berbagai tantangan di kemudian hari. ${ }^{11}$ Betapa pentinnya orang tua mempersiapkan kepercayaan diri dan kemandirian anak serta melatih sikap tanggung jawab pada anak yang dapat dimulai dari hal-hal yang kecil di rumah. Sebab beberapa sikap ini menjadi pondasi bagi anak untuk bijak dalam bersikap di kemudian hari sehingga mampu menghadapi berbagai tantangan dalam kehidupan.

\section{Pola Pengasuhan Anak Usia Dini}

Anak usia dini adalah mereka yang berusia belum matang, yakni rentang usia 0-6 tahun. Mereka umumnya tidak bisa melakukan kegiatan dalam kehidupan secara mandiri melainkan memerlukan bantuan dari orang tua. Dalam UU Sisdiknas pasal 1 butir 14 dijelaskan bahwa PAUD adalah suatu upaya pembinaan yang ditujukan kepada anak sejak lahir sampai dengan usia enam tahun yang dilakukan melalui pemberian rangsangan pendidikan untuk membantu pertumbuhan dan perkembangan jasmani dan rohani agar anak memiliki kesiapan dalam memasuki pendidikan lebih lanjut. Pada usia tersebut anak-anak perlu berbagai macam layanan dan bantuan dari orang dewasa, dari kebutuhan jasmani dan rohani, di mana bentuk layanan tersebut diarahkan untuk dapat memfasilitasi pertumbuhan dan perkembangan sebagai pondasi awal anak dalam melanjutkan proses hidup dalam kehidupannya. Layanan dan bantuan pertama yang diterima oleh anak berasal dari lingkungan keluarga. Keluarga merupakan lingkungan pertama dan utama tempat anak memperoleh bantuan di tengah ketidakmampuannya menyelesaikan berbagai masalah dan juga mengajari tentang segala sesuatu di awal kehidupannya. Keluarga yang terdiri dari ibu, ayah, kakak dan adik memiliki peran yang sangat besar dalam kehidupan anak. Ayah dan ibu memiliki tanggung jawab

\footnotetext{
${ }^{11}$ Chugani, Anak Yang Cerdas Anak Yang Bermain, 21.
} 
yang besar dalam memperhatikan kebutuhan anak, seperti kebutuhan papan, pangan, pendidikan, kesehatan, kasih sayang, serta memperhatikan pertumbuhan dan perkembangan anak.

Setiap keluarga memiliki gaya pengasuhan yang berbeda dalam mendidik anak-anaknya. Pengasuhan yang diberikan oleh orang tua memberikan pengaruh terhadap pembentukan karakter dan perilaku anak. Karakter dan perilaku yang dibentuk sangat menentukan kematangan seseorang dalam melakukan sebuah tindakan ataupun penyelesaian masalah. Oleh sebab itu pola pengasuhan menjadi hal yang penting untuk diperhatikan. Pendidikan orang tua memiliki pengaruh terhadap pola pengasuhan terhadap anak. Selain faktor pendidikan, faktor lain yang berpengaruh terhadap pola asuh yakni, pengalaman orang tua dalam mengasuh anak, keterlibatan orang tua dalam mengasuh anak, usia orang tua, stres yang mungkin dialami orang tua, dan hubungan antara suami istri di dalam keluarga. ${ }^{12}$ Pola asuh yang baik dan tepat menjadi faktor terbentuknya karakter dan perilaku terpuji pada anak.

Dalam kehidupan sehari-hari anak banyak belajar dari apa yang ia lihat dari pada apa yang ia dengar. Oleh sebab itu sebagai upaya dalam penanaman karakter yang baik, maka orang tua perlu memberikan keteladanan. Pembiasaan dan keteladanan sebagai sebuah pendekatan merupakan cara yang efektif dalam pembentukan karakter anak. ${ }^{13}$ Selain itu pengasuhan yang tepat terhadap anak dapat mengoptimalkan tumbuh kembang anak agar dapat menjadi pribadi yang kuat dan mandiri yang tidak bergantung pada orang lain. ${ }^{14}$ Begitu besar peran orang tua terhadap pertumbuhan dan perkembangan anak, sehingga orang tua harus mau untuk banyak belajar tentang bagaimana menjadi orang tua yang baik dan benar yang berorientasi pada pertumbuhan dan perkembangan anak.

Menurut Hurlock, Hardys dan Heyes dalam Wibowo, pola asuh orang tua terhadap anak dibagi menjadi tiga jenis, yakni pola asuh otoriter, demokratis, dan permisif. ${ }^{15}$ Pola asuh ororiter adalah pola asuh yang mengharuskan agar anak patuh pada segala kehendak orang tua. Pola asuh ini memicu anak untuk memiliki kecenderungan kurang inisiatif dalam melakukan hal apapun, sering cemas dan merasa rendah diri. Sedangkan pola asuh demokratis adalah pola asuh yang memberikan kebebasan pada anak untuk berkehendak tetapi dalam pengawasan orang tua sehingga anak akan menjadi seorang individu yang mempercayai orang lain, tanggung jawab terhadap tindakannya, dan ia akan menjadi seorang anak yang

12 Thridonanto, Mengembangkan Pola Asuh Demokratis (Jakarta: Gramedia, 2014).

${ }^{13}$ Wilis Werdiningsih, "Pengembangan Nilai Karakter Siswa Dalam Pendidikan Agama Islam Dan Budi Pekerti Jenjang SMP Pada Kurikulum 2013," Jurnal Cendekia 15 (2017): 302.

${ }^{14} \mathrm{Ni}$ Putu Intan Suskandeni dkk, "Hubungan Pola Asuh Orang Tua Terhadap Kemandirian Anak Usia Pra Sekolah Di TK Negeri Pembina Lombok Barat 2017," Prosiding Seminar Nasional Psikologi Unissula, Mei 2018, 104.

${ }^{15}$ A Wibowo, Pendidikan Karakter Usia Dini (Yogyakarta: Pustaka Pelajar, 2012). 
jujur. Sementara pola asuh permisif adalah pola asuh yang memberikan kebebasan sepenuhnya pada anak untuk bertindak. Apapun yang menjadi kehendak anak diperbolehkan oleh orang tua sehingga anak akan menjadi seorang yang kurang disiplin, semena-mena dan tidak bertanggung jawab. Pentingnya pola asuh karena berpengaruh terhadap pertumbuhan anak, maka orang tua perlu memastikan pola asuh yang diberikan pada anak harus tepat dan sesuai dengan kebutuhan anak.

Pola asuh responsif gender berkaitan dengan pemahaman dalam menata (1) lingkungan fisik, (2) lingkungan sosial, internal dan eksternal, (3) pendidikan internal dan eksternal, (4) dialog dengan anak-anak, (5) suasana psikologis, (6) sosiobudaya, (7) perilaku yang ditampilkan pada saat terjadinya pertemuan dengan anak-anak serta (8) kontrol terhadap perilaku anak-anak. ${ }^{16}$ Pembelajaran yang responsif gender adalah pembelajaran yang dirancang dan dirumuskan dengan parameter keadilan dan kesetaraan gender terutama dilihat dari aspek akses, partisipasi, kontrol dan perolehan manfaat. ${ }^{17}$ Akses adalah kapasitas untuk menggunakan sumberdaya untuk sepenuhnya berpartisipasi secara aktif dan produktif (secara sosial, ekonomi dan politik) dalam masyarakat termasuk akses ke sumberdaya, pelayanan, tenaga kerja dan pekerjaan, informasi dan manfaat. Misalnya kesempatan yang sama untuk laki-laki dan perempuan dalam memilih jurusan pendidikan sesuai dengan minat dan bakatnya. Partisipasi adalah mengambil bagian atau peran dalam setiap aspek di kehidupan masyarakat. Kontrol yakni baik perempuan maupun laki-laki mempunyai kontrol yang sama dalam penggunaan sumber daya. Dan manfaat artinya baik laki-laki maupun perempuan sama-sama dapat mengambil manfaat dari aktivitas yang dilakukan.

Selanjutnya pola pengasuhan yang responsif gender dapat dilihat dari bebas tidaknya pengasuhan dari komponen stereotipe, subordinasi dan marginalisasi. ${ }^{18}$ Stereotipe yang dimaksud adalah pelabelan negatif yakni cap yang diberikan oleh salah satu anggota keluarga kepada anak usia dini berdasarkan jenis kelaminnya. Misalnya saja penunjukkan kata-kata tidak pantas, tidak patut, tidak pantas, tidak cocok, "saru" dan sebagainya yang didasarkan pada jenis kelamin tertentu berdasarkan budaya yang berkembang. Adapun pemahaman subordinasi adalah kondisi di mana tidak ada lagi penomorduaan baik pada anak perempuan maupun anak laki-laki. Orang tua dan anak, baik anak perempuan maupun laki-laki di dalam keluarga mempunyai peran yang adil dan seimbang sesuai dengan kemampuannya. Selanjutnya aspek marginalisasi berkenaan dengan tidak adanya ungkapan atau

${ }^{16}$ Kemendikbud, Pengarusutamaan Gender Buku I: Panduan Pembinaan Keluarga Yang Responsif Gender (Jakarta: Direktorat Jenderal Pendidikan Anak Usia Dini, Nonformal \& Informal Dan Direktorat Pembinaan Pendidikan Masyarakat, 2014), 11.

17 Dewi S.M., "Pengembangan Model Pembelajaran Responsif Gender Di PAUD Ainina Mejobo Kudus," Jurnal Thufula PGRA STAIN Kudus 1 Nomor 1 (2013): 127.

${ }_{18}$ Muafiah dkk, "Pengasuhan Anak Usia Dini Berspektif Gender Dalam Hubungannya Terhadap Pemilihan Permainan Dan Aktivitas Keagamaan Untuk Anak," 9. 
upaya yang menyudutkan posisi anak baik anak perempuan maupun anak laki-laki. Marginalisasi atau peminggiran membatasi anak untuk dapat berkembang sesuai dengan minat dan bakatnya. Hal ini semestinya tidak terjadi sebab setiap anggota di dalam keluarga berhak untuk mendapatkan kesempatan belajar baik formal maupun non formal.

\section{Konsep Mubadalah}

Kata mubadalah adalah berasal dari bahasa Arab. Kata ini berasal dari suku kata ba da - la, yang berarti mengganti, mengubah dan menukar. Al Quran menggunakan kata ini sebanyak 44 kali dalam berbagai bentuk kata dengan makna seputar itu. Kata mubadalah merupakan bentuk kesalingan (mufa'alah) dan kerja sama antar dua pihak (musyarakah) untuk makna tersebut, yang berarti saling mengganti, saling mengubah atau saling menukar satu sama lain.

Dalam kamus modern, Al Mawrid, untuk Arab-Inggris, karya Dr. Rohi Baalbaki, kata mubadalah diartikan muqabalah bi al mitsl, yang bermakna menghadapkan sesuatu dengan padanannya. Kemudian kata ini diterjemahkan ke dalam bahasa Inggris dengan beberapa makna, yakni reciprocity, reciprocation, repayment, requital, paying back, returning in kind or degree. Sedangkan dalam kamus bahasa Indonesia, kata "kesalingan" digunakan untuk hal-hal "yang menunjukkan makna timbal balik".

Dari beberapa makna asal kata mubadalah, maka mubadalah dikembangkan menjadi sebuah perspektif dan pemahaman dalam relasi tertentu antara dua pihak, yang mengandung nilai dan semangat kemitraan, kerja sama, kesalingan, timbal balik dan prinsip resiprokal. ${ }^{19}$ Relasi dalam pembahasan ini, membahas berbagai relasi yang mungkin ada pada kehidupan manusia, yakni negara dan rakyat, majikan dan buruh, orang tua dan anak, guru dan murid atau mayoritas dengan minoritas, antara laki-laki dan perempuan, antara laki-laki dan laki-laki atau antara perempuan dengan perempuan, baik dalam skala lokal maupun global. Namun pembahasan mubadalah dalam kaitannya denga kesetaraan dan keadilan gender lebih dimaknai dengan relasi yang terjalin antara laki-laki dan perempuan di ruang domestik maupun publik. Relasi yang didasari pada kemitraan dan kerja sama. ${ }^{20}$ Dengan demikian, prinsip mubadalah tidak hanya dikhususkan untuk mereka yang berpasangan, tetapi juga mereka yang menjalin relasi dengan orang lain.

Namun kunci dari berbagai relasi yang terjalin tersebut, adalah relasi antara perempuan dan laki-laki. Dari prinsip kemitraan dan kerja sama, istilah mubadalah digunakan sebagai sebuah metode interpretasi terhadap teks-teks sumber Islam yang meniscayakan laki-laki dan perempuan sebagai subjek yang setara, yang keduanya disapa oleh teks dan harus tercakup dalam makna yang terkadung dalam teks tersebut. Sehingga secara sederhana konsep mubadalah memiliki dua pengertian,

\footnotetext{
${ }^{19}$ Kodir, Qira'ah Mubadalah, 59.

${ }^{20}$ Kodir, 244.
} 
pertama, relasi kemitraan-kesalingan antara laki-laki dan perempuan dan kedua, bagaimana sebuah teks Islam mencakup perempuan dan laki-laki sebagai subjek dari makna yang sama.

Dalam QS Al Baqarah ayat 30, dijelaskan bahwa Allah Swt. menciptakan manusia di muka bumi sebagai khalifah. Penunjukkan tugas kekhalifahan ini tidak hanya kepada kaum laki-laki tetapi juga kaum perempuan. Selanjutnya QS At Taubah: 71 merupakan ayat yang paling pokok dalam perspektif kesalingan, yakni sebagai berikut:

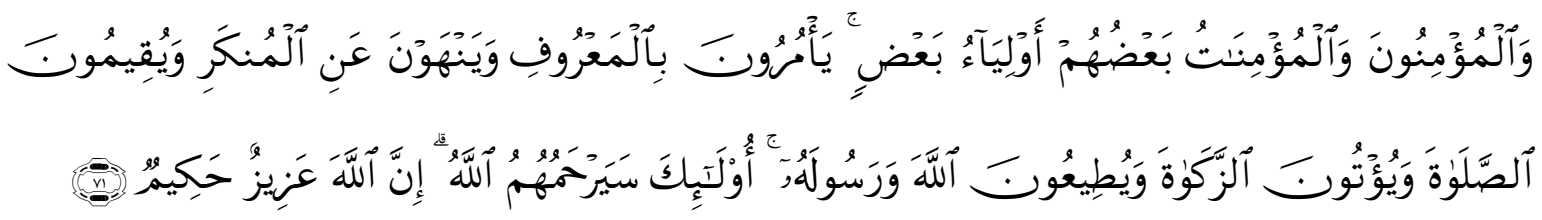

Artinya: Dan orang-orang yang beriman, lelaki dan perempuan, sebahagian mereka (adalah) menjadi penolong bagi sebahagian yang lain. mereka menyuruh (mengerjakan) yang ma'ruf, mencegah dari yang munkar, mendirikan shalat, menunaikan zakat dan mereka taat pada Allah dan Rasul-Nya. Mereka itu akan diberi rahmat oleh Allah; Sesungguhnya Allah Maha Perkasa lagi Maha Bijaksana.

Ayat tersebut menjadi pondasi dalam menafsirkan ayat-ayat tentang kekhalifahan manusia di muka bumi. Bahwa kekhalifahan manusia mencakup lakilaki dan perempuan. Oleh sebab itu sangat tidak berdasar jika berkembang anggapan perempuan sebagai separuh manusia atau separuh kaum laki-laki. Sehingga satu jenis kelamin merasa lebih superior atau lebih utama dibandingkan yang lain, sementara jenis kelamin lainnya berada pada posisi inferior. Laki-laki dan perempuan diciptakan untuk saling melengkapi, saling tolong menolong, saling bekerja sama demi menghadirkan kebaikan dan menjauhkan dari keburukan untuk kemakmuran bumi Allah sebagaimana amanah kekhalifahan manusia.

Prinsip mubadalah menekankan pada kemitraan atau kesalingan laki-laki dan perempuan dalam kehidupan. Dengan prinsip ini sebagaimana laki-laki yang ingin diakui keberadaannya, dihormati pilihannya, didengar suaranya, dan dipenuhi segala keinginannya, maka perempuanpun sama. Para perempuan juga layak untuk diakui keberadaannya, dihormati pilihannya, didengar suaranya dan dipenuhi keinginannya. Perspektif kesalingan ini akan membuahkan cara pandang yang memanusiakan manusia laki-laki dan perempuan. Sebuah cara pandang yang mengarah pada relasi yang setara dan timbal balik untuk kebaikan hidup antara laki-laki dan perempuan, sebagai modal untuk mencapai kesejahteraan laki-laki dan perempuan dalam kehidupan di ranah domestik maupun publik.

Perspektif kesalingan mengakar pada tauhid sosial yang menegaskan kesetaraan, keadilan, kasih sayang dan penghormatan kemanusiaan. Sebagaimana Ibnu al Qayyim al Jauziyah, ketentuan-ketentuan ajaran dan hukum Islam mewujudkan empat pilar nilai, yakni keadilan, kearifan, kasih sayang dan 
kemaslahatan. ${ }^{21}$ Gagasan mubadallah meniscayakan kesetaraan dan keadilan dalam berelasi antara laki-laki dan perempuan, dan mendorong hadirnya kerja sama yang partisipatif, adil dan memberi manfaat kepada keduanya tanpa diskriminasi. Ruang publik tidak hanya diperuntukan bagi kaum laki-laki, sementara ruang domestik juga tidak hanya dibebankan kepada kaum perempuan saja. Partisipasi di keduanya, baik publik maupun domestik harus dibuka seluas-luasnya bagi laki-laki maupun perempuan secara adil.

\section{Hasil Penelitian}

\section{Konsep Mubadalah Dalam Pola Pengasuhan Anak}

Beberapa hal yang perlu diperhatikan dalam pengasuhan anak adalah bahwa masa anak-anak merupakan masa penting dalam tahapan tumbuh kembang anak. Pertumbuhan dan perkembangan pada masa ini akan berpengaruh terhadap pertumbuhan dan perkembangan pada masa selanjutnya. Secara berturut-turut pertumbuhan fisik merupakan hal pertama yang perlu diperhatikan oleh sebab itu, orang tua perlu memastikan fisik anak berkembang dengan baik sesuai dengan tahap perkembangannya. Seluruh kegiatan pembelajaran pada anak akan efektif jika dilakukan melalui kegiatan bermainnya, sebab bermain merupakan pekerjaan anak. Melalui kegiatan bermain anak bisa belajar tentang budi pekerti, matematika, membaca, ataupun menulis, termasuk mengembangkan kemampuan motoriknya.

Pola asuh demokratis merupakan pola asuh yang memberikan kebebasan yang bertanggung jawab pada anak. Dalam pola asuh ini anak bebas berkehendak tetapi tetap dalam pengawasan orang tua. Sehingga anak terlatih untuk menjadi seorang yang mandiri dan percaya diri karena bisa mengungkapkan apa yang ia inginkan, sekaligus menjadi seorang yang bertanggung jawab atas apa yang ia kerjakan. Percaya diri, mandiri dan bertanggung jawab merupakan hal penting untuk ditanamkan pada anak sedini mungkin.

Sebagai upaya penerapan konsep mubadalah dalam pola pengasuhan anak dapat dilakukan melalui penekanan indikator kesetaraan gender yakni dilihat dari aspek akses, partisipasi, kontrol dan manfaat. Keempat indikator tersebut diuraikan sebagai berikut:

a. Dalam pengasuhan anak usia dini, maka baik anak laki-laki maupun perempuan diberikan kesempatan yang sama untuk dapat mengakses sumber daya fisik (terlihat) maupun non fisik (yang tidak terlihat). Mengakses sumber daya fisik yang dimaksudkan ialah anak diberikan kesempatan untuk memilih, mencoba, dan berlatih alat-alat rumah tangga yang ada di rumah. Misalkan anak laki-laki diizinkan untuk mengenal peralatan dapur dan mencoba untuk menggunakannya. Ataupun anak perempuan diizinkan untuk mengenal

${ }^{21}$ Kodir, 101. 
peralatan pertukangan seperti obeng, palu, tang yang mungkin ia ingin mempelajari penggunaannya.

b. Dalam hal partisipasi, maka baik anak perempuan maupun anak laki-laki diberikan kesempatan yang sama untuk mengambil bagian dalam setiap kegiatan di rumah. Misalnya dalam kegiatan berkebun, mencuci motor-mobil, memasak, mengepel, mencuci baju, menjemur, melipat dan menyetrika baju maka orang tua dapat melibatkan anak laki-laki maupun perempuan. Tidak ada lagi pemilahan antara pekerjaan anak laki-laki dan perempuan. Termasuk dalam kegiatan musyawarah keluarga. Orang tua harus memberikan penekanan kesempatan yang sama bagi anak perempuan dan laki-laki dalam mengutarakan pendapatnya.

c. Kontrol berkaitan dengan pengambilan keputusan. Maka dalam hal ini baik anak perempuan maupun laki-laki diberikan kesempatan untuk bertanggung jawab dalam setiap pekerjaan di rumah. Misalnya ketika orang tua pergi, maka orang tua memberikan tanggung jawab yang sama dan seimbang kepada anakanaknya baik anak perempuan maupun laki-laki untuk menjaga rumah.

d. Manfaat berkaitan dengan kewenangan untuk dapat mengambil manfaat segala fasilitas yang ada di rumah.

Dengan demikian dapat disimpulkan bahwa penerapan konsep mubadalah dalam pola pengasuhan anak dapat dilakukan dengan menekankan prinsip kesalingan antara anak laki-laki maupun perempuan untuk secara bersama-sama, bekerja sama, bermitra dalam melakukan seluruh kegiatan di rumah. Tidak ada laki penggolongan pekerjaan berdasarkan jenis kelamin, termasuk pemberian hak pada anak-anak laki-laki maupun perempuan untuk memilih segala sesuatu yang ia inginkan selama itu baik tanpa dilihat dari nilai kepantasan berdasarkan jenis kelamin. Keluarga yang mungkin memiliki anak laki-laki saja ataupun anak perempuan saja, maka perlu untuk memberikan pemahaman tentang kesamaan hak dan kewajiban antara anak-anak laki-laki dan perempuan di dalam kehidupan. Sehingga penanaman orang tua sejak kecil dapat dipahami anak dan dapat ia terapkan di dalam kehidupan di masyarakat.

Selanjutnya pola pengasuhan yang responsif gender dapat dilihat dari bebas tidaknya pengasuhan dari komponen stereotipe/pelabelan negatif, subordinasi dan marginalisasi. Orang tua harus meniadakan atau menghilangkan pelabelan negatif pada anak, baik anak laki-laki maupun perempuan. Pelabelan negatif yang dimaksud misalnya anak perempuan lembut, cengeng, penakut, lemah, sementara anak laki-laki kuat, pemberani, tidak cengeng, ataupun asas kepantasan ataupun tidak pantas dalam melakukan sesuatu yang didasarkan atas budaya setempat. Pelabelan negatif ini tidak hanya merugikan anak perempuan tetapi juga anak lakilaki, sebab pelabelan menekan anak untuk menunjukkan ekspresi yang mungkin 
tidak sesuai dengan yang ia inginkan hanya karena asas kepantasan dan tidak berdasarkan apa yang berkembang di masyarakat.

Aspek subordinasi menekankan bahwa tidak ada penomorduaan pada pengasuhan anak laki-laki maupun perempuan. Orang tua harus memberikan kesempatan yang sama pada anak perempuan dan laki-laki untuk berperan secara adil dan seimbang dalam kehidupan di keluarga. Anak laki-laki dan perempuan harus berada pada level yang sama pada setiap pengasuhan. Tidak ada laki pembagian pekerjaan rumah berdasarkan jenis kelamin melainkan berdasarkan kapasitas dan kemampuan masing-masing anak.

Selanjutnya marginalisasi atau peminggiran adalah tidak ada lagi ungkapan atau upaya yang menyudutkan posisi anak perempuan maupun laki-laki. Misalnya hanya anak perempuan saja yang boleh bermain drama memasak atau hanya anak laki-laki yang boleh memanjat, atau hanya anak perempuan saja yang boleh menangis sementara anak laki-laki tidak boleh cengeng. Ungkapan tersebut mengandung penyudutan bagi anak berdasarkan jenis kelamin, yang semestinya larangan orang tua pada anak perempuannya memanjat bukan karena memanjat adalah pekerjaan laki-laki melainkan karena memanjat pada ketinggian tertentu dapat membahayakan dirinya.

Hal yang terpenting selanjutnya dalam pengasuhan anak adalah pemilihan permainan. Dalam penekanan konsep mubadalah maka orang tua harus berupaya untuk memposisikan anak agar dapat mengakses semua permainan yang bermanfaat untuk perkembangan fisik maupun psikisnya. Tidak ada lagi permainan yanga hanya pantas dilakukan oleh anak laki-laki semisal sepak bola, ataupun permainan yang hanya pantas dilakukan oleh anak perempuan semisal bermain bekel dan bermain tali (semprengan). Orang tua perlu menekankan bahwa anak laki-laki maupun perempuan sama-sama dapat mengakses permainan sesuai dengan yang diinginkan dan dapat bermain bersama-sama untuk saling bekerja sama dalam sebuah permainan.

\section{Implementasi Konsep Mubadalah Dalam Pola Pengasuhan Anak}

Implementasi konsep mubadalah dalam pola pengasuhan anak dapat dilakukan dengan pemahaman terkait konsep mubadalah itu sendiri. Bahwa konsep mubadalah berbicara tentang adanya prinsip kesalingan, dalam bekerja sama, bermitra, berrelasi antara laki-laki dan perempuan di dalam kehidupan manusia. Allah Swt. menciptakan manusia laki-laki dan perempuan di bumi ini, di mana keduanya sama-sama merupakan subjek dari kehidupan sehingga keduanya harus bermitra untuk dapat mencapai kebahagiaan dalam hidup.

Implementasi pada tahapan selanjutnya dapat diterapkan orang tua dengan berdasarkan indikator kesetaraan gender yang dapat dilihat pada tabel berikut ini:

Tabel 3.1 Implementasi Konsep Mubadalah Dalam Pola Pengasuhan Anak

\begin{tabular}{|c|c|c|c|c|}
\hline Aspek & Akses & Partisipasi & Kontrol & Manfaat \\
\hline Permainan & Orang tua perlu & Orang tua & Orang tua & Orang tua \\
\hline
\end{tabular}




\begin{tabular}{|c|c|c|c|c|}
\hline & $\begin{array}{c}\text { memperkenalkan } \\
\text { berbagai macam } \\
\text { permainan, baik } \\
\text { permainan } \\
\text { tradisional } \\
\text { maupun modern } \\
\text { yang baik bagi } \\
\text { pertumbuhan dan } \\
\text { perkembangan } \\
\text { anak. Orang tua } \\
\text { mengizinkan anak } \\
\text { bahkan } \\
\text { mendorong anak } \\
\text { dengan } \\
\text { memberikan } \\
\text { wawasan untuk } \\
\text { mau mencoba } \\
\text { berbagai macam } \\
\text { permainan } \\
\text { tersebut. }\end{array}$ & $\begin{array}{c}\text { memberikan } \\
\text { kesempatan } \\
\text { sepenuhnya } \\
\text { pada anak } \\
\text { perempuan } \\
\text { maupun laki- } \\
\text { laki untuk } \\
\text { berpartisipasi } \\
\text { dalam } \\
\text { permainan } \\
\text { bersama } \\
\text { teman- } \\
\text { temannya. }\end{array}$ & $\begin{array}{c}\text { memberikan } \\
\text { kepercayaan } \\
\text { pada anak } \\
\text { perempuan } \\
\text { maupun laki- } \\
\text { laki untuk } \\
\text { bertanggung } \\
\text { jawab } \\
\text { sepenuhnya } \\
\text { pada } \\
\text { permainan } \\
\text { yang ia pilih. }\end{array}$ & $\begin{array}{c}\text { memberikan } \\
\text { kesempatan } \\
\text { pada anak } \\
\text { untuk } \\
\text { memperoleh } \\
\text { manfaat dari } \\
\text { setiap } \\
\text { permainan. }\end{array}$ \\
\hline $\begin{array}{l}\text { Kegiatan } \\
\text { di rumah }\end{array}$ & $\begin{array}{c}\text { Orang tua } \\
\text { mengizinkan/ } \\
\text { mendorong anak } \\
\text { untuk melakukan } \\
\text { semua kegiatan } \\
\text { rumah sebagai } \\
\text { sarana belajar } \\
\text { anak tanpa } \\
\text { memilah-milah } \\
\text { pekerjaan untuk } \\
\text { anak laki-laki } \\
\text { maupun anak } \\
\text { perempuan. } \\
\text { Semua anggota } \\
\text { keluarga berhak } \\
\text { berperan dalam } \\
\text { kegiatan di rumah } \\
\text { sesuai dengan } \\
\text { kemampuan } \\
\text { masing-masing. }\end{array}$ & $\begin{array}{c}\text { Orang tua } \\
\text { memberikan } \\
\text { kesempatan } \\
\text { sepenuhnya } \\
\text { kepada anak } \\
\text { untuk } \\
\text { mengambil } \\
\text { bagian pada } \\
\text { setiap } \\
\text { kegiatan di } \\
\text { rumah. }\end{array}$ & $\begin{array}{c}\text { Orang tua } \\
\text { memberikan } \\
\text { kepercayaan } \\
\text { pada anak } \\
\text { perempuan } \\
\text { maupun laki- } \\
\text { laki untuk } \\
\text { bertanggung } \\
\text { jawab } \\
\text { sepenuhnya } \\
\text { pada kegiatan } \\
\text { yang } \\
\text { dilakukan di } \\
\text { rumah. }\end{array}$ & $\begin{array}{l}\text { Orang tua } \\
\text { memberikan } \\
\text { kesempatan } \\
\text { pada anak } \\
\text { untuk } \\
\text { memperoleh } \\
\text { manfaat dari } \\
\text { kegiatan di } \\
\text { rumah. }\end{array}$ \\
\hline
\end{tabular}




\section{KESIMPULAN}

Pendidikan pada anak usia dini merupakan tahapan penting dalam pertumbuhan dan perkembangan anak. Pendidikan ini dimulai dari lingkungan keluarga, di mana orang tua memiliki peran penting. Oleh sebab itu orang harus memastikan lingkungan yang kondusif bagi pertumbuhan anak dan memberikan pengasuhan yang tepat, sehingga anak dapat tumbuh menjadi anak yang sehat, kuat, mandiri, percaya diri dan bertanggung jawab. Keteladanan dari orang tua menjadi hal yang harus diperhatikan, sebab anak banyak belajar dari apa yang ia lihat.

Masa usia dini merupakan masa yang tepat untuk menerapkan pengasuhan yang responsif gender sebagai salah satu upaya untuk memutus mata rantai budaya bias gender sejak dini. Seorang anak yang telah mendapatkan pendidikan responsif gender dalam kehidupan sehari-harinya di rumah, maka ia akan mampu menerapkannya di lingkungan sekolah maupun masyarakat. Sebab seringkali ketidakadilan gender berawal dari kehidupan keluarga yang masih menganut budaya patriarki dalam pengasuhan anak. Oleh sebab itu peran keluarga dalam hal ini orang tua, dalam memberikan pengasuhan pada anak sangat penting.

Konsep mubadalah merupakan salah satu konsep dalam kesetaraan gender yang menekankan pada kemitraan dan kerja sama dari dua orang yang berrelasi untuk sama-sama berkontribusi sesuai dengan kemampuan masing-masing sehingga keduanya dapat mengambil manfaat dari kerja sama tersebut. Prinsip kesalingan menjadi pondasi dari konsep mubadalah yang sejalan dengan fitrah bahwa manusia tidak bisa hidup sendiri melainkan berdampingan dengan manusia lainnya. Allah Swt. menciptakan manusia laki-laki dan perempuan, di mana keduanya menjadi subjek dari kehidupan sehingga posisi keduanya setara. Konsep ini menjadi konsep yang relevan untuk diterapkan dalam pengasuhan anak sehingga anak dapat belajar tentang kesetaraan gender sedini mungkin. 


\section{DAFTAR RUJUKAN}

Chugani, Shoba Dewey. Anak Yang Cerdas Anak Yang Bermain. Jakarta: PT Gramedia Pustaka Utama, 2009.

Kemendikbud. Pengarusutamaan Gender Buku I: Panduan Pembinaan Keluarga Yang Responsif Gender. Jakarta: Direktorat Jenderal Pendidikan Anak Usia Dini, Nonformal \& Informal Dan Direktorat Pembinaan Pendidikan Masyarakat, 2014.

Kodir, Faqihuddin Abdul. Qira'ah Mubadalah. Yogyakarta: Ircisod, 2019.

Mariyana Dkk. Pengelolaan Lingkungan Belajar. Jakarta: Kencana Perdana Media Group, 2010.

Muafiah dkk, Evi. “Pengasuhan Anak Usia Dini Berspektif Gender Dalam Hubungannya Terhadap Pemilihan Permainan Dan Aktivitas Keagamaan Untuk Anak." Jurnal Palastren 12 (June 2019).

RD Pareira, Naomi Habi Atal dan Mariana Ikun. "Peningkatan Kemandirian Anak Usia 4-5 Tahun Melalui Bercerita." Jurnal PG PAUD Trunojoyo VI (2019).

S.M., Dewi. "Pengembangan Model Pembelajaran Responsif Gender Di PAUD Ainina Mejobo Kudus." Jurnal Thufula PGRA STAIN Kudus 1 Nomor 1 (2013).

Suskandeni dkk, Ni Putu Intan. "Hubungan Pola Asuh Orang Tua Terhadap Kemandirian Anak Usia Pra Sekolah Di TK Negeri Pembina Lombok Barat 2017." Prosiding Seminar Nasional Psikologi Unissula, Mei 2018.

Thridonanto. Mengembangkan Pola Asuh Demokratis. Jakarta: Gramedia, 2014.

Werdiningsih, Wilis. "Pengembangan Nilai Karakter Siswa Dalam Pendidikan Agama Islam Dan Budi Pekerti Jenjang SMP Pada Kurikulum 2013." Jurnal Cendekia 15 (2017).

Wibowo, A. Pendidikan Karakter Usia Dini. Yogyakarta: Pustaka Pelajar, 2012. 